\title{
A Semantic Analysis on The Students' Ability to Identify Icons and Symbol in The Third Year at Mts Al-Ulum Medan
}

\author{
Nurhalimah \\ nhalimah227@yahoo.co.id
}

\begin{abstract}
This study is talking about Semantic Analaysis on the Students' Abbility to Identify Icons and Symbols. Semantic is the technical term used to refer to the study of meaniing. Meaning of English language covers a variety of language, and there is no very general agreement either about what meaning is or about the way in which it should be described. And the reaserh took place at MTs Al-Ulum 2017/2018 Medan. The population of this study is in the third year students by taking population is $\mathbf{1 2 0}$ students. According to JallaludinRahmatsugggests using T. Yoramane formula, by taking sample is 54 students. The data of this reasearch were coleceted by interview, and text. It was calculated by using Descriptive Qualitative. The analysis of the sample was conducted by using a test for the third year studentswith English teacher. The data were tabulated by using the percentage formula, after analyzing the data, mean of students' ability to identify icons and symbols in semantic analysis are $12,05 \%$. For the average and percentage of the student's ability to identify icons and symbols in semantic analysis are $60,25 \%$. Then the answer was analyzed by found out the percentage of students' ability is more than 64 , while the percentage of the whole students' in identify icons and symbols is $60,25 \%(60,25)$. It means that in the third year students' of MTs Al-Ulum Medan are still poor in identify icons and symbols in semantic analysis.
\end{abstract}

Keywords : semantic, language, english

\section{INTRODUCTION}

Semantics is the technical term used to refer to the study of meaning. Meaning of English language covers a variety of aspects of language, and there is no ver general agreement either about what meaning is or about the way in which it should be described. Arnold gives a defenition related to the semantics, that is: "semantics is concerned by the meaning the meaning of words and how they combined to form sentence meaning". We shhould know the familiar of English words with various meaning in order to avoid misunderstanding when we were involved in both oral and written communication.

By the carefully though about the language, when you speak and the ways it is use definite conclusion and can be arrived at concerning meaning. Semantics is part of linguistic and there are including of the meaning of icon and symbols. By the carefully though about the language; when you speak and the ways it is used definite conclusion and can be arrived at concerning meaning.
Semantics is part of linguistic and there are including of the meaning of icon and symbol.

Marchand said that, :the important of understanding the icons an 4 symbols is to define cultural, objects, such as a law, a constitution, a marriage ceremony, all the nouns In the story are in this category: the robe, the scepter, the language, the subject".

In the Holy Quran Allah Subhanawata'ala (Surah ARahman: 1-5) says:

Meaning: "Ar-Rahman, we taught the holy, we create the olpeople. We taught to speak; the sun 1nd the moon obey to the rules".

From this verse of Holy Qur'an, we can see the power of Allah. Allah and the kindness to people: He creates the people, He teaches the people to speak and use langulge, the sun and the moon obey to Allah. People should realize and think about the power of God, interpretation it and o rules.

Allah has explain his might I the Holy Qur'an there is about sigs whereas, it could is an existences of icons and symbols ad a signs for human to knowing that in this universes, in order to we always thinking and curtaining.

The student's have problems to identify icons and symbols occur in daily lives. First, they not yet understand the meaning of the icons and symbols, second, they cannot recognize which is the icons and besides that, the researcher is very interested to conduct the research about icons and symbols of language because the relationship of them is very closed to the translation of meaning in language. So, the research would like to analyze the students' ability in identify icons and symbols.

\section{REVIEW OF LITERATURE}

\section{Description of Semantics Analysis}

Semantic derived from Greek word "sema" meaning sign or symbol". The verb of "sema" is "semoni". "To signify or symbolize". In linguistics, semantics is the study of meaning and this is the definition that will provisionally adopt: what is to be understood by meaning in the context this statement as Lyons said.

\section{Language Type}

Language is many things-system of communication a medium for thought, a vehicle for literary expression, a 
social institution, a matter for political controversy, a catalyst for nation building. All human normally 3 peak at least one language and it is hard to imagine must significant social, intellectual, or artistic actively taking place in its absence. Each of us has a stake in understanding something about the nature and use of language.

\subsection{Spoken Language}

Spoken language is a human in whom the words are uttered through the mouth almo2t all language spoken language. Computer language and sign languages are spoken language. The term spoken language is language is often used in contrast to written language, the world most widely spoken language all have written forms the difference between the spoken and written version of a language can sometimes be quite extreme.

\subsection{Written Language}

Speaking and writing in origin and practice. Our ability to use language is as old as humankind, and reflects biological and cognitive modification that has accurate in the evolutionary history of our species. Writing, the representation of language by graphic signs or symbols is a comparatively recent cultural development, having occurred within the past five thousand years and only in certain parts of the world. The contrast between speech and witting comes into sharper focus when me consider that spoken language is acquired without specific formal instruction, where as writing must be taught and learned through deliberate efforts. There are entire groups of people in the world today, as individuals in every literate society, who are unable to write, while spoken language comes naturally to human beings, writing does not.

\subsection{Silent Reading}

Non-verbal communication represents an import2nt part of the general human communication and that it can very helpful to recognize and to classify nonverbal signals, especially with regard to the interpretation of hidden attitudes.

\section{Description Icons and Symbols}

\subsection{Icons}

Huggins said, "Iconic communication deals mainly with non verbal communication between human by the use of visual signs representations (such a picture) that stand for an idea by virtue of resemblance or analogy to it in contrast to symbolic communication where the meaning of symbols is entirely nominal (such as English text describing a picture). Pure icons, therefore, rely initially on recall of a previous visual experience on the part of the user (either first or second hand) with sufficient particularly to make their use in a particular context clear to him.

The icon is the simplest since it is a pattern that resembles what it 'stands for:

1. A picture of your face is an icon of you

2. The little square with e picture of a printer on your computer screen is an icon for the print function. (whereas a little box has the word "print is not an icon since it has no physical resemblance to printing or the printer

3. The Picture of a smoking cigarette with a diagonal bar across the picture is an icon that directly represents 'smoking" doesn't do it' (at least it does with appropriate cultural experience).

\subsection{Symbols}

Signs carry information content to be delivered to agents. However, it is also useful to understand that some signs are more easily used as references than others. In the beginning of the $20^{\text {th }}$ century, Charles Sanders Pierce defined a typology of sign.

(1) Icons are direct representation of objects. They are similar to the thing. They represent. Examples are pictorial road signs, Scale models, and of course the icons on your computer. A footprint on the sand is an icon of a foot.

(2) Symbols are arbiter representation of objects, which require exclusively a social convention to be understood. A road sign with a red circle and a white background denotes something. Which is illegal because we have agree on its arbitrary meaning to emphasize the convention aspect of the semantics of symbols, consider the example of variations in road sign: examples the diamond signs denote cautionary warnings where as in Europe a red triangle over a white back grounding (decoding) the information contained in symbols. For instance, smoke is an index of fire but if we agree on and appropriate code (e.g Morse code) we can use signals to communicate symbolically).

Hatch mentioned, "the symbols is of course, the linguistic element the word sentence, etc and the referent' the object etc. in the word of experience, while though or reference is concept. According to the theory there is no direct link between symbols and referent (between language and the word), the link via the light or reference the concept of our minds.

A symbol is something such as an object, picture, written word, sound, or particularly mark that represents something else by association, resemblance, or convention, for example, a red octagon may for :stop", on maps, crossed sabers may indicate a battlefield. Numerals are symbols for human.

The word "symbols" came to the English language, by way of Middle English. Old French and Latin from $\sigma u \mu \beta 0 \lambda$ ov sumbolon from the root words $\sigma \psi \mu$ (sym) meaning "together" and $\beta$ o $\lambda$ cbole "a throw". Having the approximate meaning of "to throw (a thing) together". So "sign, ticket, or contract".

Patton says, a symbol is an arbitrary or conventional sign" or "something that for or suggest something else". A symbol, in its basic sense, is a conventional representation of a concept or quality: i.e., an idea, object, concepts are symbolic in nature and representations for these concepts are simply token artifact that are allegorical to (but do not codify) a symbolic meaning or symbolism. 
All language consists of symbols. The word "cat" is not a cat, but represents the idea of a cat. Psychology has found that people, and even animals, can respond to symbols as if they were the objects they represent. Pavlov's dogs salivate when they hear a sound which they associate with food, even if there was no food.

Tillit also explain: "human beings ability to manipulate allows them to explore the relationship between ideas, things, concept, and qualities far beyond the explorations of which any other species on earth is capable". The discipline of sometimes studies symbols in general: semantic is specifically concern with the main meaning of words our linguistic units.

\section{a. Location}

\section{METHOD}

This research was conducted at MTs Al-Ulum Medan. JalanAmliun Gang. Johar Medan. The reason of choosing of this location is:

1. This school was the town where the writer lives

2. Suitable for the ability and limited in time and finance

\section{b. Population and Sample}

Population is a set or collection of all elements processing one for more attributes of interest in field of research. In a research, sometimes a research includes all of the population as the object of the research in getting conclusion.

The population of the research in the third year at the MTs Al-Ulum 2017/2018 Medan consists of three classes. Class IX-1 consist of 40 students class IX-2 students. Here is the detail table of the population.

Table 1 population

The number of population

\begin{tabular}{|c|c|c|c|c|}
\hline No & Grade & Male & Female & Total \\
\hline 1 & IX-1 & 20 & 20 & 40 students \\
\hline 2 & IX-2 & 20 & 20 & 40 students \\
\hline 3 & IX-3 & 19 & 21 & 40 students \\
\hline & Total & 59 & 61 & 120 students \\
\hline
\end{tabular}

Source: administration Data of MTs Al-Ulum Medan 2017/2018.

\section{c. Sample}

Sample is a part or representing of population if want to research. If we will to researching a part of the population, then this research is the sample of research. All the number of the students in the third years (120 students) is the sample of the study.

The sample og this research would be taken by using Torayamane's formula to get the number of sample in this research by using the following formula:

$$
n=\frac{N}{(d)^{2}+1}
$$

Where $n$ : the number of sample

$\begin{array}{ll}\mathrm{N}= & \text { the number of population } \\ \mathrm{d}= & \text { the precision is decided } 10 \%\end{array}$

So the sample is: $n=\frac{120}{120(0,1)^{2}+1}=\frac{120}{120.0 .01+1}=\frac{120}{2,2}=54$, $54=54$

$$
n=54
$$

So the total numbers of sample was 54 students and they were taken randomly from the total of sample. To divides the sample from each class by using proportional sample:

$$
\begin{aligned}
& \text { Total sample for class IX-1 } \\
& \frac{40}{120} \times 100 \%=33,3 \%=33 \\
& \text { Class IX -I } \\
& \frac{33}{100} \times 54 \%=17,8 \%=18 \% \\
& \text { Total sample for class IX-1 } \\
& \frac{40}{120} \times 100 \%=33,3 \%=33 \% \\
& \text { Class IX-II } \\
& \frac{33}{100} \times 100 \%=17,8 \%=18 \% \\
& \text { Total sample for class IX-III }= \\
& \frac{40}{120} \times 100 \%=33,3, \%=33 \%= \\
& \text { Class IX-III } \\
& \frac{33}{100} \times 54 \%=17,8 \%=18 \%
\end{aligned}
$$

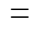

Table II sample

\begin{tabular}{|c|c|c|c|c|c|}
\hline No & Grade & Male & Female & Population & Sample \\
\hline 1 & IX-I & 20 & 20 & 40 & 18 \\
\hline 2 & IX-II & 20 & 20 & 40 & 18 \\
\hline 3 & IX-III & 19 & 21 & 40 & 18 \\
\hline & Total & 59 & 61 & 120 & 54 \\
\hline
\end{tabular}

d. Research Method

Arikunto explain that "research is action conducted by someone who works on what he's going without changing the system of the performance. In this research, the research used a descriptive quantitative method". And the quantitative method is a scientific approach that most of it's used a descriptive quantitative method. And the quantitative method is a scientific approaches that most of its used numbers for presenting the data, and the result of the research. This method describes the students' ability in identity icons and symbols in semantic analysis.

\section{e. Operation Definition}

From the theoretical conception, it could noticed that identify icons and symbols have to understand from the definition of semantic is how language organize and express meaning by the explaining some pictures of examples can helping students to make differences and can identify between icons and symbols in semantic analysis.

\section{f. Instrument of Collecting Data}

In this research the writer used two methods they were: 
1. Interview guide, the interview guide is needed when the writer interview the headmaster end teacher to go get some information about students, teaching and learning process and school condition.

2. Test, to acquire the data, the research used a set of matching tests that was administrated. The test consisted of 20 items, each correct answer was second as five and the wrong answer did not affect the score.

\section{g. Technique of Data}

The data were analysis by using descriptive quantitative technique. In this technique the data were analyzed in term if quantitative analysis. The steps in this technique were performed as follow:

1. Giving the test of identity the icons and symbols

2. Collecting the students' answer sheet

3. Finding out the correct and incorrect answer and concluding in the students' result.

4. Calculating the students' average score by using percentage formula:

\section{totalof thestudents'score}

\section{totalitemtest} $x 100 \%$

5. The data analyzed by using the following formula:

$$
\begin{array}{ll}
\mathrm{Q}= & \frac{N}{K} \times 100 \% \\
\mathrm{Q}= & \text { percentage of correct items } \\
\mathrm{N}= & \text { The number of correct items } \\
\mathrm{K}= & \text { The number of items }
\end{array}
$$

\section{RESULTS AND DISCUSSION}

\section{The Description of Data}

After giving the third year students of MTs Al-Ulum 2017/2018 Medan, test in identify icons and symbols in person and number, the writer gave some clues to the students. And the clues to do the test are as follows:

a. Distribution the test materials to the students

b. Giving instruction to the students that they should have directly done on the test paper.

c. Specifying the time for the students to do the test

d. Reading the direction on how the test should be done

e. Collecting the test papers of the students when the time was up

\section{Data Analysis \\ The Test Analysis}

The data number of score gave to each student is fully depended on the number of correct items they made. Each corrects the following table shows the individuals'

\begin{tabular}{|c|c|c|}
\hline No & Names of Students & Raw Score \\
\hline 1 & Nurul Aida & 15 \\
\hline 2 & SeptianaOniza S & 15 \\
\hline 3 & MuhmmadRidho & 15 \\
\hline 4 & Puja Yuni S & 15 \\
\hline 5 & Febri K & 14 \\
\hline 6 & M. Hafizh Al-hijr & 14 \\
\hline 7 & Putri A & 14 \\
\hline 8 & UmmiAtiah & 14 \\
\hline 9 & Dana Iswara & 14 \\
\hline 10 & DidiWahyudi & 14 \\
\hline 11 & DindaBestari & 14 \\
\hline 12 & EgiDarmawan & 14 \\
\hline 13 & Maharani & 14 \\
\hline 14 & KartikaAnanda & 13 \\
\hline 15 & Lola Evi & 13 \\
\hline 16 & NurAnisa & 13 \\
\hline 17 & RiskiRamahani & 13 \\
\hline 18 & SuciLsilstulasma & 13 \\
\hline 19 & Paramithawindasari & 13 \\
\hline 20 & Zainuddin & 13 \\
\hline 21 & FauiahFitri & 13 \\
\hline 22 & M. Ilham & 13 \\
\hline 23 & Putri Nadia & 13 \\
\hline 24 & RahmatAryRizki & 13 \\
\hline 25 & RamadhanNapolis & 12 \\
\hline 26 & SamsulArifin & 12 \\
\hline 27 & AbiNega & 12 \\
\hline 28 & Ade Kurniawan & 12 \\
\hline 29 & Ahmad yasir & 12 \\
\hline 30 & Sri devi & 12 \\
\hline 31 & WulanHendrika & 12 \\
\hline 32 & M. Danu & 12 \\
\hline 33 & NurAsysyah & 12 \\
\hline 34 & AjisSuharman & 12 \\
\hline 35 & AgungPrasetyo Koto & 11 \\
\hline 36 & Ayuresti & 11 \\
\hline 37 & Miranda Dara & 11 \\
\hline 38 & FrederikHambali & 11 \\
\hline 39 & M. ArifFaill & 11 \\
\hline 40 & Ahmad zulkifli & 11 \\
\hline 41 & Dina apnani & 11 \\
\hline 42 & LusyFradila & 11 \\
\hline 43 & RisaAyu & 11 \\
\hline 44 & RizkiSwardana & 10 \\
\hline 45 & A. Haris. Nst & 10 \\
\hline 46 & M. Rifai & 10 \\
\hline 47 & Nurhasanah & 10 \\
\hline 48 & SelamatZulfahmi & 10 \\
\hline 49 & UmiKalsumHrp & 10 \\
\hline 50 & RandaPrasetyo & 9 \\
\hline 51 & Bobby Hidayat & 9 \\
\hline 52 & Lisa Fitri & 9 \\
\hline 53 & Fitruani & 8 \\
\hline 54 & TiffaaniArifa. C. & 8 \\
\hline
\end{tabular}
score:
Table III

The Raw of the Students' Score about Test 
The score used in order to compute the mean, the standard Deviation, Validity and Reliability. Before setting up the mean scores and standard, the raw scores arrange in a frequency distribution. The procedures are:

a. Determining the lowest and the biggest score. The highest score $(\mathrm{H})$ is 15 and the lowest $(\mathrm{L})$ is $\mathrm{R}$

b. Making use of an appropriate formula to fix the total range, that is

$\mathrm{R}=\mathrm{H}-\mathrm{L}+1$

$\mathrm{R}$ is total range, $\mathrm{H}$ means highest score, $\mathrm{L}$ identifies lowest score, for the consonant of member. So the total range is $15(\mathrm{H})-8(\mathrm{~L})+1=11$

c. Putting the data in details as many as they fell in each score.

d. Calculating the tallies to find out the frequency (f). see table II

Table IV

Frequency Distribution of the Score in Indentify Icons and Symbols

\begin{tabular}{|c|c|c|}
\hline Interval & Tallies & Frequency \\
\hline 15 & III I & 4 \\
14 & III IIIIII & 9 \\
13 & III IIIIIIIII & 11 \\
12 & III IIIIII I & 10 \\
11 & III IIIIII & 9 \\
10 & III III & 6 \\
9 & III & 3 \\
8 & II & 2 \\
Total & & $\mathbf{N}=\mathbf{5 4}$ \\
\hline
\end{tabular}

The Mean

The mean is gained with using a particular as follows:

Table V

Computation of Mean

\begin{tabular}{|c|c|c|}
\hline Score $(\mathbf{X})$ & F & FX \\
\hline 15 & 4 & 60 \\
14 & 9 & 126 \\
13 & 11 & 143 \\
12 & 10 & 120 \\
11 & 9 & 99 \\
10 & 6 & 60 \\
9 & 3 & 27 \\
8 & 2 & 16 \\
\hline & $\mathbf{N = 5 4}$ & $\sum \boldsymbol{f x}=\mathbf{6 5 1}$ \\
\hline
\end{tabular}

Thus, from computation of mean (M) from the table above $\mathrm{N}=60$ and $\sum f x=651$ and found out mean formulation is:

\section{Standard Deviation}

$$
M x=\frac{\sum f x}{N}=\frac{651}{54}=12,05
$$

Table II helped the writer standard deviation. The procedures are as follow:
Table VI

Computing of the Standard Deviation

\begin{tabular}{|c|c|c|c|c|}
\hline $\begin{array}{c}\text { Score } \\
(\mathbf{X})\end{array}$ & $\mathbf{f}$ & $\mathbf{f X}$ & $\mathbf{X}^{\mathbf{2}}$ & $\mathbf{f X}^{\mathbf{2}}$ \\
\hline 15 & 4 & 60 & 225 & 900 \\
14 & 9 & 126 & 196 & 1764 \\
13 & 11 & 143 & 169 & 1859 \\
12 & 10 & 120 & 144 & 1440 \\
11 & 9 & 99 & 121 & 1085 \\
10 & 6 & 60 & 100 & 600 \\
9 & 3 & 27 & 81 & 243 \\
8 & 2 & 16 & 64 & 128 \\
\hline & $\mathbf{N =}$ & $\mathbf{f X}$ & $\sum \boldsymbol{X}^{\mathbf{2}}$ & $\sum \boldsymbol{f X}^{\mathbf{2}}$ \\
& $\mathbf{5 4}$ & $\mathbf{= 6 5 1}$ & $\mathbf{1 1 0 0}$ & $=\mathbf{8 0 1 9}$ \\
\hline
\end{tabular}

Therefore, reconvert into the formula:

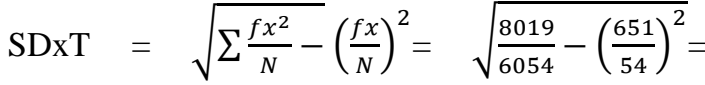

$$
\begin{aligned}
& \sqrt{148,5}-\left({\frac{423801^{2}}{2916}}^{2}\right) \\
& =148,5-145,33=1,72
\end{aligned}
$$

Note: $\mathrm{SD}=$ Standard Deviation

$\sum f x=$ The Sum of multiplication the frequency by the $\mathrm{X}$

$\sum f X^{2}=$ The Sum of multiplication the frequency by $X^{2}$

Validity of the Test

$$
N \quad=\text { Number of case }
$$

A Test is valid if it measures what it purpose measure. Here, valid the material or the contents of the test which had been arranged as to be to measure and specific objectives and also the students for what they had studied before:

Where:

$r x y=$ index score of correlation between $\mathrm{x}$ variable and y variable variable

$\sum f x=$ Total number of $\mathrm{x}$ variable and $\mathrm{y}$

$\sum x^{2}=$ Quadrate of $\mathrm{x}$

$\sum y^{2}=$ Quadrate of $y$

Referring to the table VII the formula to claim whether the test is valid or no, the procedure is:

$$
r x y=\sqrt{\frac{\sum \square \square}{\left(\sum \square^{2}\right)\left(\sum \square 2\right)}}=\sqrt{\frac{1937}{(2043)(2106)}}=\frac{1937}{\sqrt{(4302558)}}=\frac{1937}{2074,2}=0,
$$

Thu, the validity for 20 items of the test is 0,93 . It is considered valid, because it is agreed with the following suggestion calculating of validity.
$0,800-1,00=$ very high
$0,600-0,800=$ high
$0,400-0,600=$ moderate
$0,200-0,200=$ low
$0,00-0,200=$ very low 
Therefore, it is provided that the validity of the test is very high.

\section{The Reliability of the Test}

Reliability is the agreement or accuracy of a test evaluation. The consistency of measurement obtained from and instrument is referring or stabile and productive. To prove whether the test is reliable or not, the writer med split half method. The calculated from the result of the method was the data formula of product moment. By seeing table VIII above, the procedures are:
a. $\mathrm{M} x=\frac{\sum x}{N}=\frac{327}{54}=6,05$
b. b. $\mathrm{My}=\frac{\sum y}{N}=\frac{324}{54}=6$
c. $\mathrm{SD}_{x}=\sqrt{\frac{\sum x^{2}}{N}}=\sqrt{\frac{2043}{54}}=\sqrt{37,83}=6,17$
d. $\mathrm{SD}_{y}=\sqrt{\frac{\sum y^{2}}{N}}=\sqrt{\frac{2106}{54}}=\sqrt{39}=6,24$

The formula is:

$$
r x y=\frac{\sum f x}{N S D_{x} S D_{y}}=\frac{1937}{(54)(6,15)(6,24)}=\frac{1937}{2072,30}=0,93
$$

The reliability of the items of the test was taken from the data, and it was computed by using Spearman - Brown formula, that is: $\mathrm{r}_{11}=\frac{2^{r 1 / 2}{ }^{1 / 2}}{\left(1+1 / 2^{1} / 2\right)}$

Note: $\quad r_{11} \quad$ : Coefficient of total reliability

$$
\begin{array}{ll}
1 / 21 / 2 & \text { : Coefficient of product moment } \\
& \text { correlation between half of the first } \\
& \text { part with half of the second part. }
\end{array}
$$

When it was applied to the data, it will produce:

$$
r_{11}=\frac{2^{r 1} / 2^{1} / 2}{\left(1+1 /{ }_{2} 1 / 2\right)}=\frac{2 \square 0,93}{1+0,93}=\frac{1,86}{1,93}=0,96
$$

Thus, the reliability for 20 items of test presented in the study of identity icons and symbols in person and number is 0,936 . It is means very high correlation and is considered reliable, because it was based on the calculating of reliability below:

$$
\begin{array}{ll}
0,00-0,20 & =\text { No correlation } \\
0,20-0,40 & =\text { Low correlation } \\
0,40-0,70 & =\text { Moderate correlation } \\
0,70-0,90 & =\text { High Correlation } \\
0,90-1,00 & =\text { very high }
\end{array}
$$

The percentage of Students' Ability

Based on the table VII the percentages use 4 to calculate how far the students' ability in identify icons and symbols. Based on the data above, there were 24 students get middle mark, and 19 students' have low scores and 11 students' have fail scores.

The averages of percentage of the students' ability to identify icons and symbols were

Formulated by using the following computation: $\mathrm{NP}=\frac{R}{N}$ Where: $\mathbf{N P}=$ Wanted percentage, $\mathbf{R}=$ The total students' ability, $\mathbf{N}=$ The Number of Students.

$$
\mathrm{NP}=\frac{R}{N}=\frac{651}{54}=12,05 \quad \mathrm{Q}=\frac{N}{K}=\frac{12,05}{20}
$$

$=0,60 \times 100 \%=60,25 \%$

The objective of instruction could be achieve when the average of the students' ability is more than 64, the percentage of the whole students' in identification icons and symbols is $60,25 \%(60,25)$. It means that the third year students' of MTs Al-Ulum Medan were still poor in identification icons and symbols. We can compare it with the following acceptable manual.

\begin{tabular}{|c|c|c|}
\hline Point & Letter & Predication \\
\hline $90-100$ & A & Very enough \\
$80-89$ & B & Good \\
$65-79$ & C & Enough \\
$55-64$ & D & Less \\
Down -55 & E & Fail \\
\hline
\end{tabular}

\section{Finding and Discussion}

1. The students have mistake in identify icons and symbols. In the previous chapter we have seen the result of the test show that the most of the students are not capable to identify icons and symbols in semantics analysis. The students' difficulty in identify icons of no 1 PLN (High Level Electricity), no 2 Mickey Mouse, and they have mistake in matching answer from no 9 and no 10, where they are only 5 students who had ability in answering the test correctly. The students difficulty in identify symbols in matching answer from no 4 and 10, where the students only 2 students ability in correct answer the symbols of the test.

\section{Interpretation}

The interpretations that are drawn from analyzed that data on the test as follows;

a. The average percentage that was obtained from the test in identification icons and symbols in semantics analysis is $60,25 \%$.

b. Comparing the result mentioned above, it shown that the third year students' of MTs Al-Ulum Medan are unable to matching the answer from the test.

c. Based on the hypothesis, many students of MTs AlUlum Medan get trouble in identify icons and symbols.

\section{Findings}

There are some findings from the analysis of the data in this research. The findings are:

1. The mean of the students' ability in identify icons and symbols is 12, 05 meanwhile the standard deviation is 1,78 .

2. The students of third year at MTs Al-Ulum 2017/2018 Medan are still to make the mistake when to identify icons and 2 ymbols in semantic analysis.

3. The school has complete facilities for learning English by the facilitating the students with the language laboratory and a complete library for the students to read. 
4. The English teachers were graduated from S1 Degree from different University, so that their capabilities are qualified for teaching the students.

Conclusion and suggestions

\section{CONCLUSIONS}

After analyzing and interpreting the test given to the students, the writer comes to some conclusion:

1. The finding show the result from the test of the students' ability in identify icons and symbols in semantic analysis in person and number, the writer finds out $12,05 \%$. For the average and percentage of the students ability to identify icons and symbols in semantic analysis are $60,25 \%$. The finding shows that the hypothesis in the earlier chapter is accepted. Based on calculated how far students' ability in identify icons and symbols. The calculation how far students' ability in identify icons and symbols, the calculation of the data, there are 24 students get middle mark, 19 students' have low scores and 11 students' have fail scores. In the third year students of MTs Al-Ulum Medan.

2. The percentage of the students' ability in icons items (x) is $6,15 \%$, and the students' ability in symbols items (y) 6, 24\%.

3. Based on the data, the students still make a lot of error in identify icons and symbols in semantic analysis, kinds of mistake are follow:

- Students' difficult in identify icons items of no 1 PLN (High Level Electricity), no 2 Mickey Mouse.

- $\quad$ Students have mistake in matching answer icons items no 9 and 10 .

- Students' difficulty in identify symbols items in matching answer from no 4 and 10.

4. From the test result of Third Year students' MTs AlUlum Medan, the teacher not focusing this problem in their English Subject, so they are get trouble in identify icons and symbols.

\section{Suggestion}

After drawing the conclusion, the research suggest as follow:

1. English teacher should explain and make focus the students by using various ways to understand the use of icons and symbols in order to improve the students' ability in semantic analysis.

2. The students who had low marks and should increase their ability in identify icons and symbols by practicing.
3. The writer suggest in third year MTs Al-Ulum Medan to concern more deeply in identify the icons and symbols in their English Subject.

\section{REFERENCES}

Arikunto, Suharsimi. ProsedurePenelitian: SuatuPendekatanPraktik, Jakarta: BinaAksara, 1996.

Arnold, Michael. The Language Style, London: Longman, 1995.

Beardon C \& Dorman C. Saying Thing with Practice: A Theoretical Approach to Iconic Communication, RSRC Research Repot 93002, University of Bringthon, 1992.

Chaer, Abdul. LinguistikUmum, Jakarta: RienekaCipta, 1997.

Ellis, Rod. Understanding Second Language Acquisition, Oxford: Oxford, University Press, 1985. 